Power and Status in the Roman Empire, AD 193-284 


\section{Impact of Empire}

Editorial Board of the series Impact of Empire (= Management Team of Impact of Empire) Lukas de Blois, Angelos Chaniotis Ségolène Demougin, Olivier Hekster, Gerda de Kleijn Luuk de Ligt, Elio Lo Cascio, Michael Peachin John Rich, and Christian Witschel

Executive Secretariat of the Series and the Network

Lukas de Blois, Olivier Hekster Gerda de Kleijn and John Rich Radboud University of Nijmegen, Erasmusplein 1, P.O. Box 9103, 6500 HD Nijmegen, The Netherlands

Academic Board of the International Network Impact of Empire GÉZA ALFÖLDY - STÉPHANE BENOIST - ANTHONY BIRLEY CHRISTER BRUUN - JOHN DRINKWATER - WERNER ECK - PETER FUNKE ANDREA GIARDINA - JOHANNES HAHN - FIK MEIJER - ONNO VAN NIJF MARIE-THÉRÈSE RAEPSAET-CHARLIER - JOHN RICHARDSON BERT VAN DER SPEK - RICHARD TALBERT - WILLEM ZWALVE

VOLUME 12 


\title{
Power and Status \\ in the Roman Empire, \\ AD 193-284
}

\author{
By \\ Inge Mennen
}

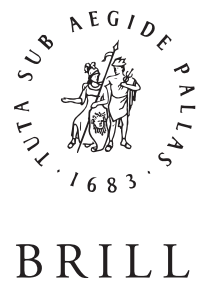

LEIDEN • BOSTON

2011 
This book is printed on acid-free paper.

Library of Congress Cataloging-in-Publication Data

Mennen, Inge.

Power and status in the Roman Empire, AD 193-284 / by Inge Mennen.

p. cm. - (Impact of empire, ISSN $1572-0500$; v. 12)

Includes bibliographical references and index.

ISBN 978-90-04-20359-4 (hbk. : acid-free paper) 1. Rome-Politics and government-30

B.C.-284 A.D. 2. Rome-Social conditions. 3. Rome-History-Empire, 30 B.C.-284 A.D. 4. Power

(Social sciences)-Rome-History. 5. Rome-Officials and employees-Selection and

appointment-History. 6. Social classes-Rome-History. 7. Social status-Rome-History. 8.

Imperialism-Social aspects-Rome-History. 9. Political culture-Rome-History. 10.

Hierarchies-Rome-History. I. Title. II. Series.

DG298.M46 2011

937.07-dc22

2011006724

ISSN $1572-0500$

ISBN 9789004203594

Copyright 2011 by Koninklijke Brill NV, Leiden, The Netherlands.

Koninklijke Brill NV incorporates the imprints Brill, Hotei Publishing,

IDC Publishers, Martinus Nijhoff Publishers and VSP.

All rights reserved. No part of this publication may be reproduced, translated, stored in a retrieval system, or transmitted in any form or by any means, electronic, mechanical, photocopying, recording or otherwise, without prior written permission from the publisher.

Authorization to photocopy items for internal or personal use is granted by Koninklijke Brill NV provided that the appropriate fees are paid directly to The Copyright Clearance Center, 222 Rosewood Drive, Suite 910, Danvers, MA 01923, USA.

Fees are subject to change. 


\section{CONTENTS}

Acknowledgements ..................................... vii

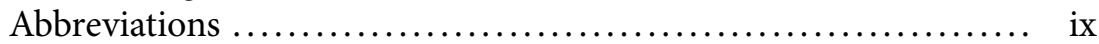

List of Tables and Figures............................... xi

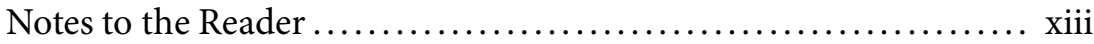

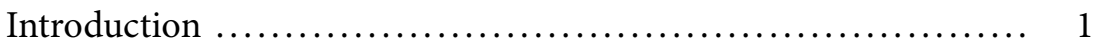

Chapter One. Changing Emperorship: Setting the Scene ......... 21

1.1. Factors Influencing Emperorship between AD 193 and 284 .. 22

1.2. Consequences for the Position of the Emperor ............ 40

1.3. Conclusion ...................................... 46

Chapter Two. The Impact of Crises on the Position of the Senatorial Elite ....................................... 49

2.1. Establishing the Senatorial Elite in the Third Century....... 50

2.2. Analyzing the Selected Families ..................... 55

2.3. Defining a Nucleus within the Senatorial Elite............ 70

2.4. Conclusion ........................................ 79

Excursus. Prosopography of the Senatorial Elite Families......... 83

Chapter Three. Praetorian Prefects and Other High-ranking

Equestrians ........................................... 135

3.1. The Increasing Responsibilities of High Equestrians in Imperial Administration ............................. 137

3.2. The Status of High-ranking Equestrians in the Third Century ......................................... 156

3.3. The praefecti praetorio: A Case Study .................... 159

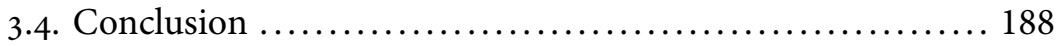


Chapter Four. High-ranking Military Officers: Septimius Severus versus Gallienus .......................................... 193

4.1. Septimius Severus and His Military Officers ............... 194

4.2. Gallienus and His Military Officers ..................... 216

4.3. Conclusion ...................................... 240

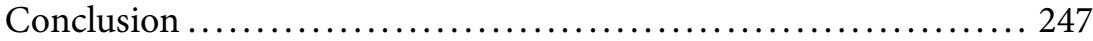

Appendix One. List of Emperors and Usurpers (AD 193-284) ...... 255 Appendix Two. Lists of Men Holding Senatorial Elite Positions

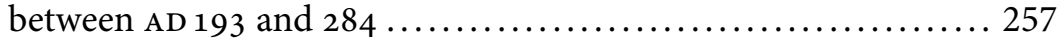
Appendix Three. List of Praefecti Praetorio between AD 193 and 284263

Bibliography ........................................... 269

General Index ............................................ 289

Index of Ancient Persons ..................................... 297 


\section{ACKNOWLEDGEMENTS}

Roman imperial administration as well as power and status relations are fascinating, though complicated, topics of research. For this study, I had to become familiar with these complex themes, examining, within about half a decade, a period of over a hundred years. It may come as no surprise that this was not always easy. Fortunately, the generous support of others helped me along the way. I would like to express my gratitude to those who helped me complete this book, which is a slightly revised version of my doctoral dissertation (Radboud University, 2010).

First and foremost I am exceptionally grateful to Lukas de Blois, whose enthusiasm, infinite trust, and support have been essential stimuli to my research. I have benefited greatly from his inexhaustible knowledge on the third century and its administration. Olivier Hekster, whose speed of speech and thought are peerless, regularly saved me from circular arguments and methodological errors. His comments and questions helped me to improve my texts and put things in a wider perspective. I have received the friendship, encouragement and feedback of my fellow team members of the 'Image and Reality' project, Daniëlle Slootjes and Erika Manders. Lien Foubert and Janneke de Jong commented thoughtfully and helpfully on my ideas and parts of my thesis as well. I want to thank them both for being close friends.

During my PhD years I had the opportunity to spend considerable time abroad, at inspiring institutes and in excellent libraries. This also afforded me the chance to meet some people who helped me develop my ideas. At Heidelberg, I learned a lot about epigraphy and discussed my research at a very early stage with Géza Alföldy and Christian Witschel. During my stays at Oxford, I received a warm welcome from Edward Bispham, Alan Bowman and Fergus Millar and profited from their expertise. In New York, I was fortunate to meet Michael Peachin, with whom I had valuable conversations on the use of prosopography in examining Roman administration and who agreed to be a member of my thesis committee. I am grateful for his stimulating comments. Pierre Sánchez welcomed me to Geneva and enabled me to work there. Noemi Poget is to be thanked for showing me around the Genevan libraries. It was there that the first 
chapter of this study took shape. Finally, I would like to thank the staff of the Royal Netherlands Institute in Rome, and especially Gert-Jan Burgers, for the hospitality they extended to me.

I am greatly indebted to David DeVore, who advised me and improved my English most acutely. He came highly recommended, but still exceeded all expectations. Needless to say, any remaining errors are my responsibility. Warm thanks are given to all colleagues of the History department at the Radboud University, especially my fellow ancient historians.

My friends and in-laws are to be thanked for their encouragements and expressing interest in my work. I wish to thank my parents and my sister for their unconditional support and love. The final words of thanks are reserved for Folkert, who is probably the only physicist who is an expert on both particle accelerators and third-century Roman imperial administration: his love, support, optimism and patience have been indispensable. I am extremely thankful for everything he did.

This project, which is part of the larger research program 'Image and Reality of Roman Imperial Power, AD 193-284', could not have been carried out without the financial support provided by the Netherlands Organisation for Scientific Research (NWO). Thanks are also due to the Radboud University of Nijmegen, the EU's Lifelong Learning Programme Erasmus, the Royal Netherlands Institute in Rome (KNIR), the Prins Bernhard Cultuurfonds and the Stichting Dr. Hendrik Muller's Vaderlandsch Fonds. An earlier version of much of section 2.2 was published in O. Hekster, G. de Kleijn and D. Slootjes (eds.), Crises and the Roman Empire. IMEM 7 (Leiden and Boston 2007). 


\title{
ABBREVIATIONS
}

\author{
AAntHung Acta Antiqua Academiae Scientiarum Hungaricae \\ AE L'Année épigraphique \\ AJPh American Journal of Philology \\ ANRW Aufstieg und Niedergang der römischen Welt \\ BJ Bonner Jahrbücher des Rheinischen Landesmuseums in Bonn und \\ Vereins von Altertumsfreunden im Rheinlande \\ BMCRE H. Mattingly, C.H.V. Sutherland, E.A. Sydenham et al., Coins of \\ the Roman Empire in the British Museum (London and Oxford \\ 1923-) \\ CAH The Cambridge Ancient History (Cambridge 1923-) \\ CCG Cahiers du Centre Gustave-Glotz \\ CIL Corpus Inscriptionum Latinarum \\ Cod. Iust. Codex Iustinianus, ed. P. Krueger (Berlin 1900-1905) \\ CP Classical Philology \\ CQ Classical Quarterly \\ CR Classical Review \\ DNP H. Cancik, H. Schneider, M. Landfester (eds.), Der Neue Pauly. \\ Enzyklopädie der Antike. 13 Bände Altertum A-Z, 5 Bände \\ Rezeptions- und Wissengeschichte A-Z, 1 Registerband (Stuttgart \\ and Weimar 1996-2003). \\ DoS J. Scott and G. Marshall (eds.), A Dictionary of Sociology (3rd \\ revised edition, Oxford 2009). \\ DSS C.J. Calhoun (ed.), Dictionary of the Social Sciences (New York \\ 2002). \\ HA Historia Augusta \\ IEph Die Inschriften von Ephesos (IGSK 11-17), 8 vols. (Bonn 1979- \\ 1984) \\ IESBS N.J. Smelser, P.B. Baltes (eds.), International Encyclopedia of the \\ Social and Behavioral Sciences (Oxford 2002). \\ IG Inscriptiones Graecae (Berlin 1903-) \\ IGBR Inscriptiones Graecae in Bulgaria Repertae \\ IGRR R. Cagnat, A. Merlin, L. Chatelain, Inscriptiones Graecae ad Res \\ Romanas Pertinentes, 3 vols. (1, 3, 4) (Paris 1906-1927). \\ ILAfr Inscriptions latines d'Afrique (Tripolitaine, Tunisie, Maroc) (Paris \\ 1923) \\ ILAlg Inscriptions latines de l'Algérie (1922-) \\ ILS H. Dessau (ed.), Inscriptiones Latinae Selectae, 3 vols. (Berlin \\ 1892-1916).
}


IMEM Proceedings of the Workshop of the International Network Impact of Empire (Roman Empire c. 200 BC-AD 476).

Inscr. It. Inscriptiones Italiae (Rome 1931-1986).

IRT J.M. Reynolds and J.B. Ward-Perkins, The Inscriptions of Roman Tripolitania (Rome 1952).

JRA Journal of Roman Archaeology

JRS Journal of Roman Studies

LCL Loeb Classical Library

MEFRA Mélanges de l'École française de Rome: Antiquité

OCD S. Hornblower, A. Spawforth (eds.), The Oxford Classical Dictionary (third revised edition, Oxford 2003).

ODE C. Soanes, A. Stevenson (eds.), Oxford Dictionary of English (second edition, Oxford 2003).

PBA Proceedings of the British Academy

PIR Prosopographia Imperii Romani Saeculi I, II, III (1897-1899, second edition 1933-)

PLRE A.H.M. Jones, J.R. Martindale, J. Morris (eds.), The Prosopography of the Later Roman Empire, 3 vols. (Cambridge 1971-1992).

P. Giss. $\quad$ O. Eger et al., Griechische Papyri im Museum des oberhessischen Geschichtsvereins zu Geissen (Leipzig-Berlin 1910-1912).

P. Oxy. $\quad$ B.P. Grenfell et al., The Oxyrhynchus Papyri (London 1898-).

$R D \quad$ Revue historique de droit français et étranger

RE A.F. Pauly, G. Wissowa and W. Kroll, Paulys Realencyclopädie der classischen Altertumswissenschaft (Munich 1894-1997).

REA Revue des études anciennes

REL Revue des études latines

RIB R.G. Collingwood, R.P. Wright (eds.), The Roman Inscriptions of Britain, vol. 1 (1965, revised edition with addenda 1995).

SCI Scripta Classica Israelica

SDHI Studia et Documenta Historiae et Iuris

SEG Supplementum Epigraphicum Graecum

TAM Tituli Asiae Minoris (Vienna 1901-)

ZPE Zeitschrift für Papyrologie und Epigraphik 


\section{LIST OF TABLES AND FIGURES}

Figure 2.1. Schematic overview of strata within the senatorial order 50

Table 2.1. Representativeness of the selected families ............ 54

Table 2.2. Geographic origin of the selected families ............. 65

Table 2.3. Patrician status of the selected families ............... 67

Table 2.4. Years in which the selected families reached consular rank 74

Table E1. The Acilii (Glabriones et Aviolae) .................. 83

Table E2. The Anicii ..................................... 86

Table E 3 . The Bruttii .................................... 89

Table E4. The Caesonii.................................. 91

Table E5. The Catii ...................................... 93

Table E6. The Claudii Pompeiani............................. 95

Table E7. The Claudii Severi ............................... 98

Table E8. The Egnatii .................................... 100

Table E9. The Fulvii Aemiliani ............................. 104

Table E10. The Hedii Lolliani................................. 106

Table E11. The Marii ........................................ 109

Table E12. The Nummii................................... 112

Table E13. The Pollieni/Pollenii ............................ 116

Table E14. The Pomponii .................................. 118

Table E15. The Postumii ................................... 121

Table E16. The Valerii ................................... 123

Table E17. The Vettii ...................................... 127

Table E18. The Virii ....................................... 130

Table 4.1. Severus' supporters in $193 \ldots \ldots \ldots \ldots \ldots \ldots \ldots \ldots \ldots . \ldots . \ldots . \ldots 194$

Table 4.2. Men involved in the battle against Niger............... 196

Table 4.3. Men involved in the first Parthian war ................. 199

Table 4.4. Men involved in the battle against Albinus ............... 201

Table 4.5. Men involved in the expeditio Britannica.............. 208

Table 4.6. Men involved in military events in the West (260-262) .. 216

Table 4.7. Men involved in military events in the East (260-262) . . 222 
Table 4.8. Gallienus' protectores............................ 227

Table 4.9. Men involved in military events at the end of Gallienus'

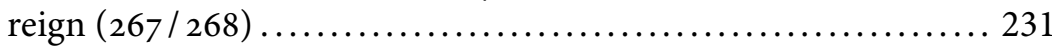




\section{NOTES TO THE READER}

Translations are taken from the $L C L$, unless otherwise noted. The numbering of Dio's Roman History follows the LCL edition.

' $193 / 205$ ' means that a person held a post for an unspecified period between 193 and 205. '193-205' means that a person held an office from 193 until 205. 